\title{
MORPHOLOGICAL AND MORPHOMETRIC CHARACTERIZATION OF PRATYLENCHUS SPECIES IN SUGARCANE CROPPING AREAS OF PERNAMBUCO STATE ${ }^{1}$
}

\author{
ALNIUSA MARIA DE JESUS ${ }^{2}$, ELVIRA MARIA REGIS PEDROSA ${ }^{3 *}$, JOÃO BATISTA RIBEIRO DA SILVA REIS ${ }^{2}$, \\ ANDRÉA CHAVES FIUZA PORTO ${ }^{4}$
}

\begin{abstract}
The root-lesion nematodes Pratylenchus spp. have a wide geographic distribution and a large number of host plants. These migratory endoparasites are found associated with sugarcane around the world causing diseases that induce permanent losses in productivity. Although this genus has ordinarily been reported in low-producing sugarcane areas in northeastern Brazil, studies of the species occurrence are few and restricted to a very low number of sites and samples. This study aimed to morphologically and morphometrically characterize Pratylenchus species from different sugarcane regions of Pernambuco state, where composite samples of soil and roots were collected on 30 farms from three sugarcane mills. The external morphological characters of the nematode body from different populations had a diagnostic value compatible with those obtained in the literature, showing the dominance of $P$. zeae $(87 \%)$ in the region. Atypical populations of the genus Pratylenchus were also found.
\end{abstract}

Keywords: Lesion nematode. Saccharum. Morphological and morphometric variation.

\section{CARACTERIZAÇÃO MORFOLÓGICA E MORFOMÉTRICA DE ESPÉCIES DE PRATYLENCHUS EM ÁREAS DE CULTIVO DE CANA-DE-AÇÚCAR DO ESTADO DE PERNAMBUCO}

\begin{abstract}
RESUMO - Os nematoides das lesões radiculares Pratylenchus spp. apresentam ampla distribuição geográfica e grande número de plantas hospedeiras. Esses endoparasitas migradores são encontrados associados à cana-deaçúcar em regiões canavieiras diversas do mundo causando doenças que induzem permanentes perdas em produtividade. A despeito deste gênero ser frequentemente relatado em áreas de baixa produtividade no nordeste do Brasil, estudos sobre espécies ocorrentes são poucos e restritos a um número muito baixo de amostras e áreas. O presente estudo teve como objetivo avaliar morfológica e morfometricamente espécies de Pratylenchus de diferentes regiões do estado de Pernambuco cultivadas com cana-de-açúcar. Amostras compostas de solo e de raízes foram coletadas de 30 fazendas de três usinas do Estado de Pernambuco. As características morfológicas externas do corpo dos nematoides das diferentes populações estudadas apresentaram valor diagnóstico compatível com aqueles obtidos na literatura nematológica, demonstrando a predominância de $P$. zeae (87\%) na região. Populações atípicas de Pratylenchus também foram encontradas.
\end{abstract}

Palavras-chave: Nematoide das lesões radiculares. Saccharum. Variação morfológica e morfométrica.

\footnotetext{
${ }^{*}$ Corresponding author

${ }^{1}$ Received for publication in 06/04/2019; accepted in 04/09/2020

Paper extracted from the postdoctoral work of the first author.

${ }^{2}$ Department of Research, Empresa de Pesquisa agropecuária de Minas Gerais, Nova Porteirinha, MG, Brazil; alniusa@epamig.br ORCID: 0000-0003-0390-1536,jbrsreis@epamig.br - ORCID: 0000-0001-5677-605X.

${ }^{3}$ Department of Agricultural Engineering, Universidade Federal Rural de Pernambuco, Recife, PE, Brazil; elvira.pedrosa@ufrpe.br ORCID: 0000-0002-0755-8352.

${ }^{4}$ Sugarcane Experimental Station of Carpina, Universidade Federal Rural de Pernambuco, Carpina, PE, Brazil; achavesfiuza@yahoo.com.br - ORCID: 0000-0002-4515-9627.
} 


\section{INTRODUCTION}

Sugarcane (Saccharum sp.) is one of the best options among renewable energy sources in the agribusiness, with an important role in the energy matrix of Brazil and other countries (OLIVEIRA, 2018). The growing search for less polluting and renewable fuels has turned the sugarcane market into one of the world's most promising in agribusinesses, favoring the expansion of the sugarcane industry. However, despite the Brazilian tradition in sugarcane production, sugarcane productivity is regulated by several factors, with health problems reducing crop productivity in different producing regions, especially those caused by nematodes (BELLÉ et al., 2017; PORTO et al., 2018).

The damage caused by nematodes varies according to the population level, soil type, and crop variety (SILVA et al., 2016; BELLÉ et al., 2017; NORONHA et al., 2017; MARANHÃO et al., 2018). When at a high population density, nematodes cause severe damage to the root system, which becomes underdeveloped and inefficient, leading to decreased productivities (SILVA et al., 2017; PORTO et al., 2018). Two nematode genera are important for sugarcane in Brazil: the root-knot nematodes Meloidogyne spp. and the root-lesion nematode Pratylenchus spp. (CHAVES et al., 2009; BELLÉ et al., 2014, 2017). Damage caused by Pratylenchus species in sugarcane fields is reported with levels of up to $52.4 \%$ for susceptible varieties, accounting for $35 \%$ of production losses (RAMOUTHAR; BHUIYAN, 2018).

Most the Pratylenchus species are polyphagous. The knowledge of species and interand intraspecific variability of nematodes is essential for the management of infestations since, by means of diagnosis, the identification of species and races allows establishing adequate crops to be explored or that will compose a rotation plan (OVERSTREET et al., 2014). However, intraspecific variability in Pratylenchus spp. has been pointed out as one of the main difficulties in the taxonomy of this group since most of the characters used for identifying the species are very variable (YU et al., 2012; MOKRINI et al., 2013; NORONHA et al., 2017).

Despite the existing techniques for characterization, some nematologists find it difficult to identify Pratylenchus species (YU et al., 2012). Morphometric characters that define nematode species may vary not only between specimens of distinct subpopulations but also among individuals belonging to the same subpopulation. Morphometric differences between subpopulations of a species may be partially influenced by environmental factors, with geographical isolation being the most prominent, followed by the host plant and temperature (OLOWE; CORBETT, 1984; DOUCET et al., 2001).

Because species of the genus Pratylenchus can be differentiated only by means of minor morphological and morphometric differences, efforts to differentiate Pratylenchus species in sugarcane fields in Northeastern Brazil are scarce and restricted to a small number of sites (SILVA et al., 2017). The main species reported in Brazil are P. brachyurus, $P$. zeae and $P$. coffeae, although more than 70 species have been reported worldwide. Few studies were carried out in Brazil to characterize Pratylenchus species, particularly populations in sugarcane fields. Thus, the aim of this study was to morphometrically characterize Pratylenchus populations in several farms cultivated with sugarcane.

\section{MATERIAL AND METHODS}

Thirty farms continuously cultivated with sugarcane were sampled at three sugarcane mills of Pernambuco state, Brazil: a) Santa Teresa Mill, located in Goiana; b) Cruangi II Mill, located in Timbaúba, and c) Salgado Mill, located in Barreiros. Five composite samples were collected from each farm. Each composite sample consisted of $2 \mathrm{~kg}$ of soil and $500 \mathrm{~g}$ of roots from three subsamples collected at the central point of sugarcane plantation of the farm. Aliquots of $250 \mathrm{~cm}^{3}$ of soil were used for extracting the nematodes according to Jenkins (1964), and $10 \mathrm{~g}$ of roots for extracting the nematodes according to blender centrifugal flotation method (BEZOOIJEN, 2006). Extracts were brought up to $40 \mathrm{~mL}$ and kept refrigerated $\left(4{ }^{\circ} \mathrm{C}\right)$, before semi-permanent slides were prepared for the specific identification. After the processing of soil and roots, 40 adult females obtained from each sample were completely measured, totalizing 1200 specimens in all study. At sampling time plants or ratoon were older than 10 months.

The following structures were measured: stylet length, diameter of the stylet bulb, overall body length (L), body diameter, \% distance of vulva from anterior end $(\mathrm{V})$, tail size, body diameter at anus height, anterior end to the end of the esophagus, anterior end to the esophagus-intestine junction, and body diameter at stylet height. In addition, the following De Man indices were calculated: a (relationship between body length and largest body width), b (relationship between body length and distance from anterior end to pharyngo-intestinal junction), b' (relationship between body length and distance from anterior end to esophagus end); c (relationship between body length and tail length), and c' (relationship between tail length and tail diameter at anus height). Pratylenchus genus was set apart from the others using keys and descriptions of Mai et al. (1996) and then identified to species level using identification keys of Castillo and Vovlas (2007) and Gonzaga and Santos (2010), under a compound microscope $(400-1,000 \mathrm{x})$.

Data analysis was performed by means of 
classical statistics by using descriptive statistics (mean, standard deviation, standard error of the mean, minimum, maximum, and coefficient of variation) using the software SAS 9.4 (SAS, 2017).

\section{RESULTS AND DISCUSSION}

Among the collected samples in the sugarcane crop-growing areas, 30 Pratylenchus populations from the different areas were identified; 26 of them (86.7\%) containing exclusively $P$. zeae and four of them $(13.3 \%)$ with atypical Pratylenchus population. The identification of $P$. zeae was initially based on the absence of males (extremely rare), a typical characteristic of this species, and vulva position ( $\mathrm{V}=$ $71 \pm 3 \%$ ) since it is in the most anterior body position.
Females of $P$. zeae had a thin body (Figure 1A) with a low lip region, but not angular and not separated from the body. Although this parameter is variable in Pratylenchus, it is more characteristic in certain species (OLOWE; CORBETT, 1984). The specimens showed a normal stylet (Figure 1B) with flattened bulbs and strong anterior projections, as shown in (Figure 1C), which is considered an important morphological character of this species (CASTILLO; VOVLAS, 2007). In addition, a clearly excretory pore, a dorsal esophageal gland overlapping the intestine (Figure 1D), and a quite developed median bulb (Figure 1E) were observed. However, the most anterior vulva position (Figure $2 \mathrm{~A}$ ) is the most outstanding diagnostic character in this species, when compared to other species from Brazil (GONZAGA; SANTOS, 2010).

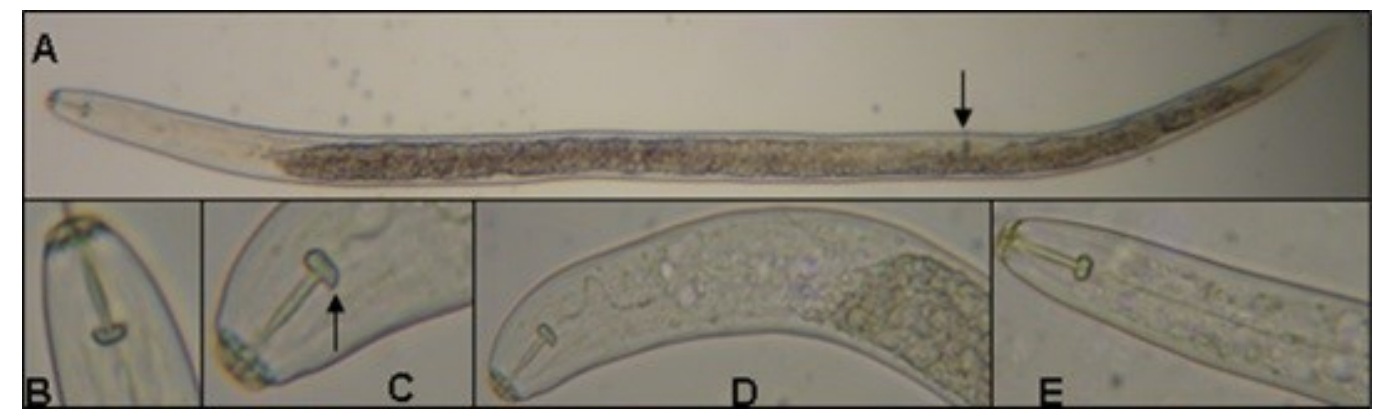

Figure 1. A) Photomicrograph of females of Pratylenchus zeae showing the thin body and vulva position (arrow). B) Lip region with a normal stylet. C) Stylet showing a bulb with an anterior projection (arrow) and typical low lip region of three lip rings as $P$. zeae. D) Visible excretory pore (arrow) and dorsal esophageal gland overlapping the intestine. E) Anterior region showing the median bulb (arrow).

To identify species of this genus, one of the main parameters analyzed is the number of lip rings present in the lip region. Some species have two rings, others four, and most commonly three lip rings, as observed in our study, which represent the majority of the species of the genus, such as P. zeae. Although most Pratylenchus species identified in our study had a constant number of rings in the lip region (three lip rings), few of them exhibited incomplete transverse annulus. On account of this variation we measured 40 adult females per sample, in line with Castillo and Vovlas (2007), who recommend to make measurements of at least 10 or 20 females of the species under study before it can be safely classified.

A narrow, subacute, rounded tail with predominant smooth terminus was observed in the species analyzed in this study (Figure 2A). Pointed and smooth tail, typical of $P$. zeae, were also observed, sometimes with a dorsally curved terminus and pointed with annuli at the end (Figure $2 \mathrm{~F}, 2 \mathrm{G}$, $2 \mathrm{H}, 2 \mathrm{I}, 2 \mathrm{~J}$ and $2 \mathrm{~L}$ ). The great variation in tail shape of the genus Pratylenchus make it a good taxonomic characteristic, however it should be the last parameter to be considered because of environmental influence and variation within species (DOUCET et al., 2001).

The post-uterine sac in $P$. zeae is short (Figure 2B) and females do not exhibit functional spermatheca, which has a round shape and most of the time is empty, without sperm (Figure 2C), a characteristic of species without males, being considered as small or absent for some authors (OLOWE; CORBETT, 1984; CASTILLO; VOVLAS, 2007). Variations in the shape of this structure may result from artifacts of preparation, such as when pressing the coverslip during preparation. The specimens were always developed showing adult females with eggs (Figure 2D) and juveniles of the second stage (Figure 2E). 


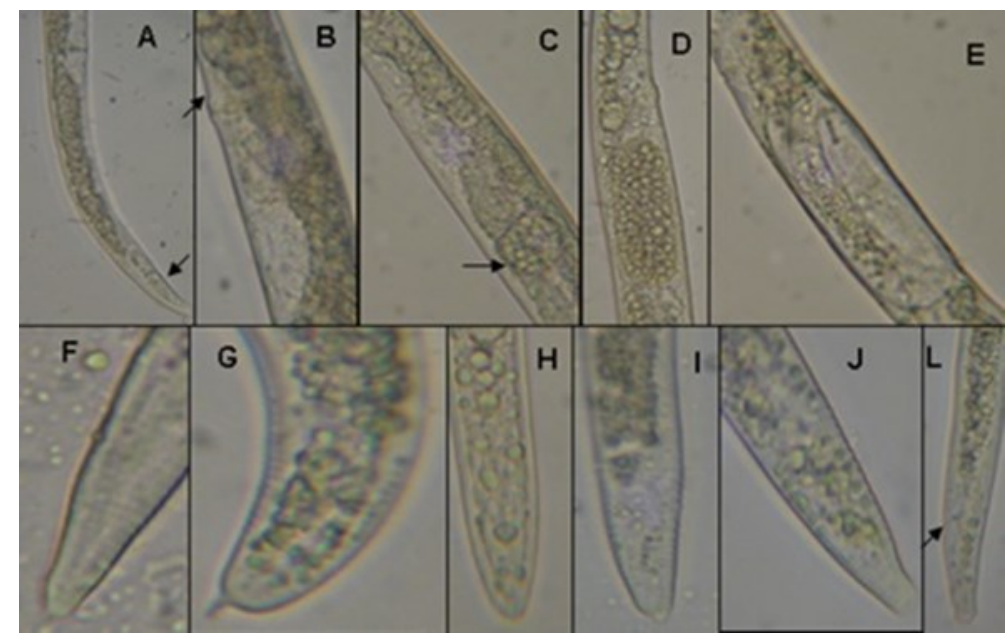

Figure 2. A) Most anterior vulva position with an arrow showing the anus. B) Photomicrograph of a female showing a short post-uterine sac (arrow). C) Short rounded spermatheca (arrow) typical of Pratylenchus zeae. D) Female of P. zeae with eggs E) and juveniles of the second stage. F-L) Variations in tail shape (L-arrow indicates the anus).

Atypical Pratylenchus population (10a, 12a, and $14 \mathrm{a}$, all of them from Goiana) regarding vulva position (Figure 3A), presented a lip region slightly different from the typical body of nematodes with three lip rings, similar to $P$. penetrans. Another similar characteristic was the predominance of a median bulb, highly developed stylet, and evident stylet muscle (Figure 3B). Tail (Figure 3C) resembles those of both $P$. penetrans and $P$. coffeae despite the predominance of a truncated tail terminus in $P$. coffeae and conical and smooth in $P$. penetrans. In addition, rectum size between species seems to have more or less the same distance (Figure 3C and 3D). Males found in the studied populations exhibited a bursa involving the entire tail (Figure $3 \mathrm{D}$ ), a characteristic that does not differentiate the main species found in Brazil, although males do not have relevant diagnostic characters for identifying the species.

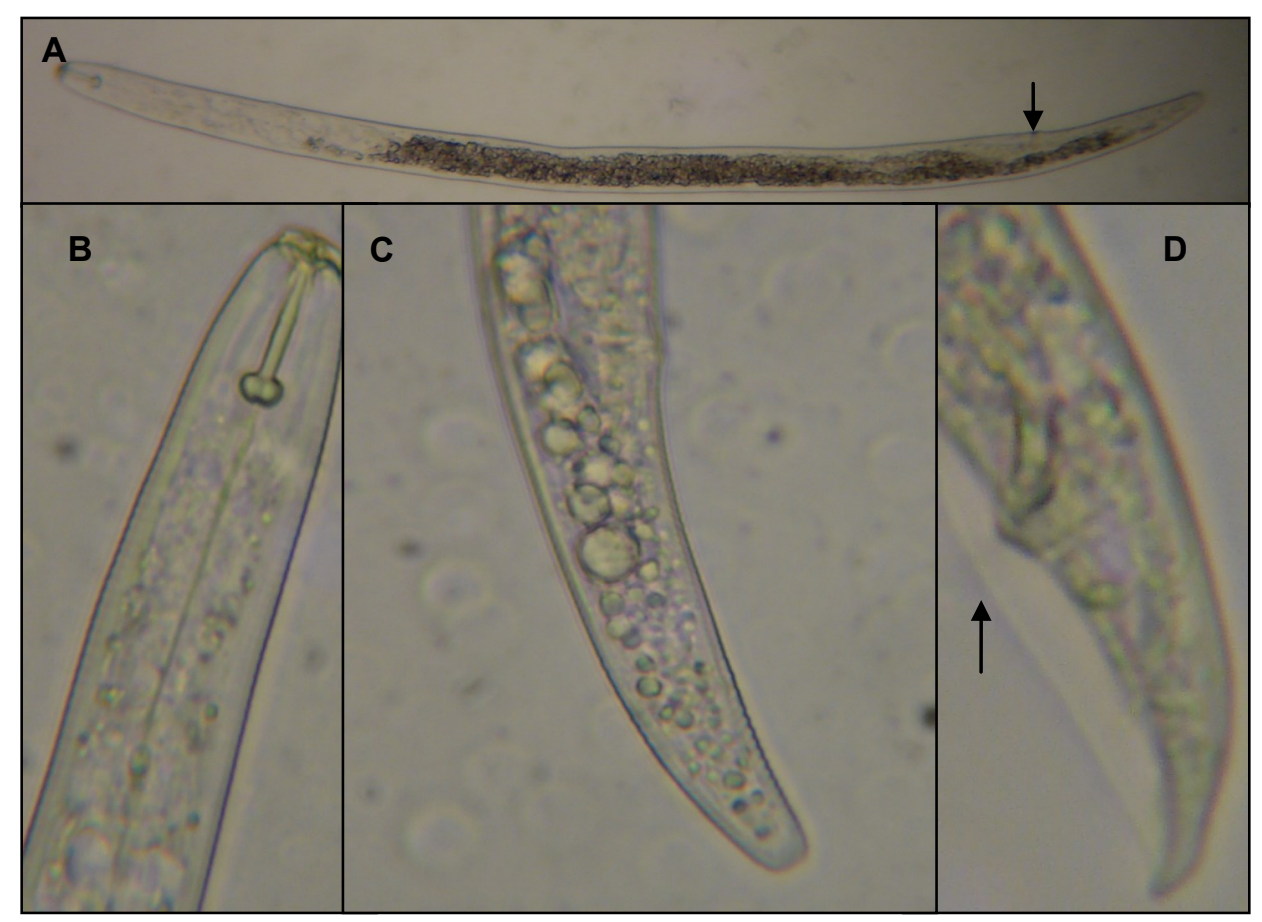

Figure 3. A) Photomicrograph of the body of Pratylenchus sp. (population 10a) showing the vulva position (arrow). B) Anterior end showing the stylet bulb and medium bulb of Pratylenchus sp. C) Photomicrograph of the tail of Pratylenchus sp. D) Posterior region of a male of Pratylenchus sp. with the bursa involving the entire tail (arrow). 
Vulva morphology of population 12 a (Figure 4A) resembles those of $P$. penetrans and $P$. coffeae. Vulva position of $P$. penetrans is not a relevant diagnostic character for identifying the nematode. No marked difference of this character was observed under the light microscope in relation to $P$. coffeae. The post-uterine sac of $P$. penetrans is short and similar to that of the studied nematode. The rounded and slightly oval spermatheca (Figure 4B) resembled that of $P$. penetrans, in contrast to the oval and functional structure in $P$. coffeae. Females of all atypical Pratylenchus populations showed a welldeveloped ovary under the light microscope (Figure 4C).

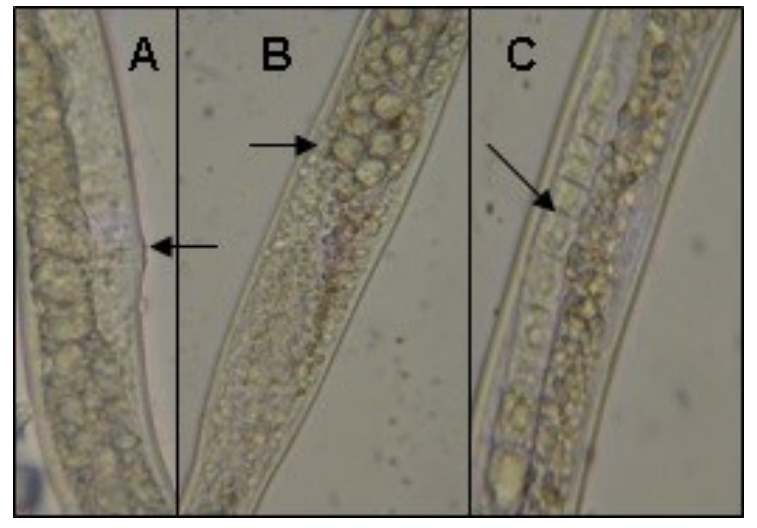

Figure 4. A) Photomicrograph of the female of Pratylenchus sp. (population 12a) showing the vulva position (arrow). B) Functional rounded spermatheca (arrow). C) Ovary showing germinative region (arrow).

The first population studied (population 1a from Goiana) also had atypical specimens. Tail size was small in relation to the body and the vulva was located in the posterior portion compared to that observed in other common species found in Brazil (Figure 5A). Well-developed females without male presence were observed, exhibiting a large and massive stylet similar to that of $P$. brachyurus (Figure 5A; Figure 5B). It was not possible to observe spermatheca and post-uterine sac as shown in (Figure 5C).

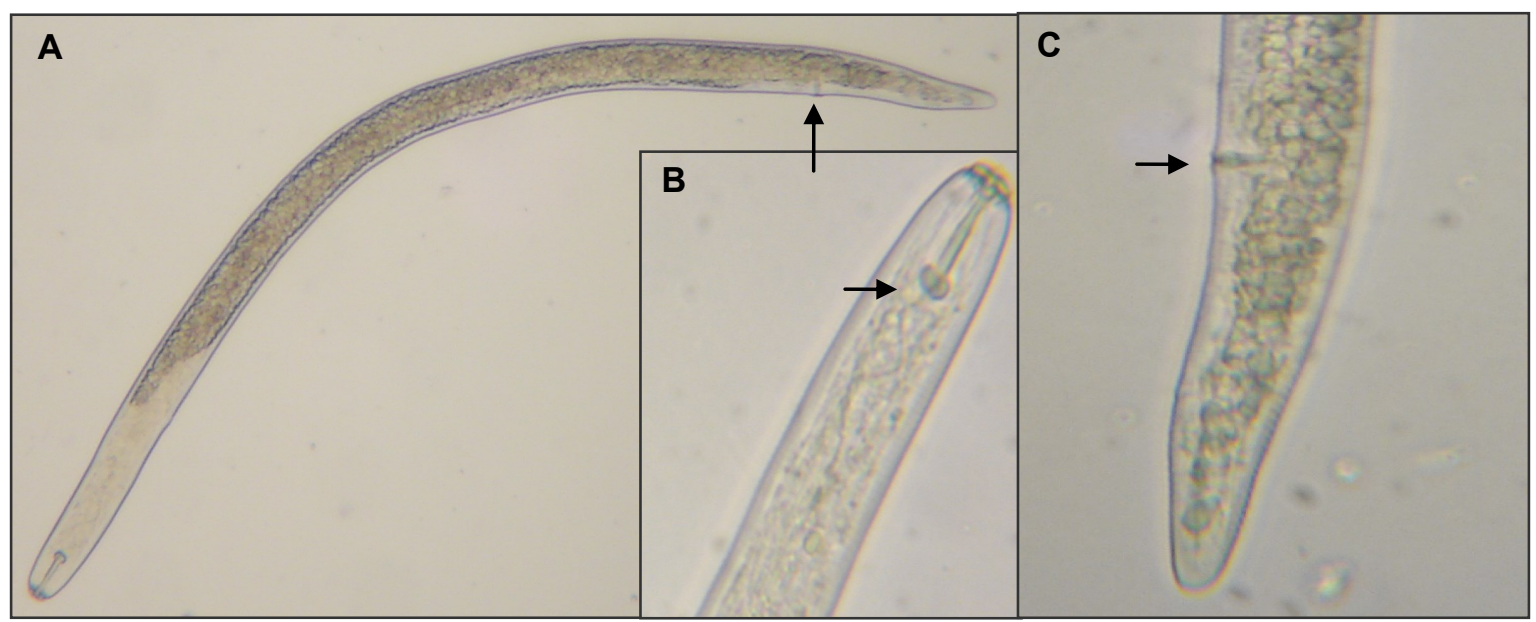

Figure 5. A) Photomicrograph of a female of Pratylenchus sp. (population 1a) with the indication of the vulva position in $\mathrm{C}$; B) Anterior region showing the stylet (arrow) with spherical basal nodules; C) Hemispheric tail as a typical smooth terminus in P. brachyurus.

In general, the analyzed variables showed small variation among the studied populations (Table 1). The variables size and width of stylet were more stable when compared to the other variables, with averages of 18.20 and 4.55 , respectively, in accordance with Castillo and Vovlas (2007) regarding $P$. zeae, which may enable the identification of this parthenogenetic species since males are very rare. In fact, body length of females ranged from 0.57 to $0.70 \mathrm{~mm}$, as shown in Table 1 . 
Table 1. Stylet length (SL), stylet bulb diameter (SBD), overall body length (L), body diameter (BD), anterior end to vulva $(\mathrm{AEV})$, tail size (T), body diameter at anus height (AD), and anterior end to the end of esophagus (LEE), measurements of anterior end to the esophagus-intestine junction (LEIJ) and body diameter at stylet (BDS),body length/largest body width (A), body length/LEE (B), body length/tail length (C), AEV /L $\times 100$ (V), L/ LEIJ (BL), tail length/DA (CL) of Pratylenchus females collected from 30 farms growing sugarcane (Saccharum sp.).

\begin{tabular}{|c|c|c|c|c|c|c|c|c|c|c|}
\hline \multirow[b]{2}{*}{ Population } & \multicolumn{10}{|c|}{ Parameter: mean/ standard deviation } \\
\hline & $\mathrm{SL}(\mu \mathrm{m})$ & $\begin{array}{l}\text { SBD } \\
(\mu \mathrm{m})\end{array}$ & $\begin{array}{c}\mathrm{L} \\
(\mathrm{mm})\end{array}$ & $\mathrm{BD}(\mu \mathrm{m})$ & $\begin{array}{l}\mathrm{AEV} \\
(\mu \mathrm{m})\end{array}$ & $\mathrm{T}(\mu \mathrm{m})$ & $\begin{array}{c}\mathrm{AD} \\
(\mu \mathrm{m})\end{array}$ & $\begin{array}{l}\text { LEE } \\
(\mu \mathrm{m})\end{array}$ & LEIJ & BDS \\
\hline \multirow[b]{2}{*}{1} & 18.09 & 4.55 & 0.59 & 25.43 & 423.85 & 168.93 & 14.70 & 131.1 & 105.46 & \\
\hline & \pm 1.02 & \pm 0.01 & \pm 0.08 & \pm 4.63 & \pm 59.27 & \pm 35.50 & \pm 2.20 & \pm 22.11 & \pm 19.38 & - \\
\hline \multirow[t]{2}{*}{ 1a } & 22.75 & 4.55 & 0.67 & 22.75 & 577.85 & 95.55 & 18.20 & 154.70 & 131.95 & - \\
\hline & 18.09 & 4.55 & 0.59 & 25.59 & 407.11 & 163.23 & 15.24 & 134.79 & 105.22 & \\
\hline 2 & \pm 0.01 & \pm 0.001 & \pm 0.07 & \pm 3.92 & \pm 61.70 & \pm 23.50 & \pm 2.41 & \pm 1.64 & \pm 21.09 & - \\
\hline \multirow{2}{*}{3} & 18.20 & 4. 55 & 0.59 & 24.68 & 426.90 & 168.23 & 14.56 & 133.54 & 104.19 & \\
\hline & \pm 0.01 & 0.01 & \pm 0.06 & \pm 3.55 & \pm 48.14 & \pm 19.83 & \pm 1.84 & \pm 16.14 & \pm 10.69 & - \\
\hline \multirow{2}{*}{4} & 18.20 & 4.55 & 0.63 & 25.93 & 453.97 & 177.56 & 14.44 & 137.97 & 108.17 & \\
\hline & \pm 0.01 & \pm 0.01 & \pm 0.07 & \pm 5.17 & \pm 60.56 & \pm 19.88 & \pm 1.75 & \pm 15.87 & \pm 10.83 & - \\
\hline \multirow{2}{*}{5} & 18.08 & 4.55 & 0.59 & 23.88 & 429.17 & 169.14 & 14.10 & 14.10 & 104.19 & \\
\hline & \pm 0.71 & \pm 0.01 & \pm 0.07 & \pm 3.04 & \pm 52.19 & \pm 30.75 & \pm 1.72 & \pm 1.72 & \pm 14.30 & - \\
\hline \multirow{2}{*}{6} & 18.08 & 4.55 & 0.63 & 25.13 & 429.91 & 180.97 & 14.44 & 136.72 & 105.78 & \\
\hline & \pm 0.71 & \pm 0.01 & \pm 0.51 & \pm 3.85 & \pm 38.16 & \pm 22.65 & \pm 1.75 & \pm 14.16 & \pm 9.97 & - \\
\hline \multirow{2}{*}{7} & 18.08 & 4.55 & 0.58 & 22.75 & 422.69 & 166.53 & 13.87 & 137.63 & 101.92 & \\
\hline & \pm 0.71 & \pm 0.01 & \pm 0.06 & \pm 2.30 & \pm 41.76 & \pm 22.78 & \pm 1.43 & \pm 17.89 & \pm 13.81 & - \\
\hline \multirow[b]{2}{*}{8} & 18.08 & 4.55 & 0.59 & 23.88 & 426.79 & 167.55 & 13.76 & 141.61 & 100.66 & \\
\hline & \pm 0.71 & \pm 0.01 & \pm 0.05 & \pm 2.47 & \pm 40.30 & \pm 17.90 & \pm 1.25 & \pm 13.55 & \pm 9.11 & - \\
\hline \multirow{2}{*}{9} & 18.20 & 4.55 & 0.63 & 23.66 & 454.09 & 176.42 & 14.21 & 148.89 & 109.88 & \\
\hline & \pm 0.01 & \pm 0.01 & \pm 0.06 & \pm 3.88 & \pm 50.77 & \pm 21.84 & \pm 2.10 & \pm 15.79 & \pm 11.35 & - \\
\hline \multirow{2}{*}{10} & 18.20 & 4.55 & 0.68 & 24.79 & 489.01 & 193.26 & 1.67 & 150.71 & 112.27 & \\
\hline & \pm 0.01 & \pm 0.01 & \pm 0.07 & \pm 3.56 & \pm 52.21 & \pm 18.22 & \pm 1.92 & \pm 16.29 & \pm 14.10 & - \\
\hline \multirow{2}{*}{$10 \mathbf{a}$} & & & 0.57 & 27.30 & 445.90 & 100.10 & 13.65 & 127.40 & 91.00 & $\begin{array}{r}18.20 \\
+227\end{array}$ \\
\hline & 18.20 & 4.55 & \pm 0.77 & \pm 31.85 & \pm 655.20 & \pm 122.85 & \pm 18.20 & \pm 195.65 & \pm 159.25 & $\begin{array}{c} \pm 22.7 \\
5\end{array}$ \\
\hline \multirow{2}{*}{11} & 18.20 & 4.55 & 0.65 & 25.48 & 467.51 & 183.13 & 14.90 & 147.87 & 112.38 & \\
\hline & \pm 0.01 & \pm 0.01 & \pm 0.64 & \pm 4.22 & \pm 46.59 & \pm 22.77 & \pm 2.05 & \pm 13.19 & \pm 989 & - \\
\hline & 18.20 & 4.55 & 0.63 & 23.89 & 455.34 & 174.83 & 14.33 & 147.53 & 110.22 & \\
\hline 12 & \pm 0.01 & \pm 0.001 & \pm 0.07 & \pm 3.82 & \pm 58.08 & \pm 23.80 & \pm 1.64 & \pm 15.13 & \pm 9.74 & - \\
\hline 129 & 18.20 & 4.55 & $0.53-$ & $22.75-$ & $386.75-$ & $122.55-$ & 1365 & $141.05-$ & 113.75 & 1820 \\
\hline $12 \mathrm{a}$ & \pm 0.01 & \pm 0.001 & 0.57 & 27.30 & 445.90 & 141.05 & 13.65 & 150.15 & \pm 122.85 & 18.20 \\
\hline 13 & 1820 & 455 & 0.68 & 24.80 & 486.74 & 193.03 & 15.24 & 152.20 & 114.66 & \\
\hline 13 & 18.20 & 4.55 & \pm 0.05 & \pm 3.25 & \pm 42.73 & \pm 17.57 & \pm 2.19 & \pm 13.27 & \pm 10.10 & - \\
\hline & 18.20 & 4.55 & 0.63 & 24.68 & 467.17 & 184.73 & 14.22 & 145.71 & 109.77 & \\
\hline 14 & \pm 0.01 & \pm 0.001 & \pm 0.11 & \pm 3.55 & \pm 46.41 & \pm 23.64 & \pm 1.52 & \pm 16.24 & \pm 13.48 & - \\
\hline $14 a$ & 18.20 & 4.55 & 0.61 & 22.75 & 486.85 & 131.85 & 13.65 & 163.80 & 109.30 & 18.20 \\
\hline & 18.20 & 4.55 & 0.65 & 24.46 & 468.99 & 187.23 & 15.02 & 143.44 & 110.79 & \\
\hline 15 & \pm 0.71 & \pm 0.001 & \pm 0.06 & \pm 3.52 & \pm 49.07 & \pm 22.72 & \pm 2.11 & \pm 15.07 & \pm 12.04 & - \\
\hline & 18.20 & 4.55 & 0.66 & 26.96 & 468.42 & 187.12 & 15.02 & 144.80 & 112.27 & \\
\hline 16 & \pm 0.71 & \pm 0.001 & \pm 0.07 & \pm 4.04 & \pm 54.06 & \pm 21.29 & \pm 2.11 & \pm 14.23 & \pm 10.87 & - \\
\hline & 18.20 & 4.55 & 0.69 & 25.14 & 487.08 & 200.66 & 14.22 & 145.73 & 117.85 & 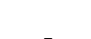 \\
\hline 17 & \pm 0.71 & \pm 0.001 & \pm 0.05 & \pm 2.91 & \pm 37.30 & \pm 21.13 & \pm 1.52 & \pm 24.76 & \pm 11.69 & - \\
\hline & 18.20 & 4.55 & 0.67 & 26.96 & 479.00 & 187.80 & 14.56 & 154.81 & 124.33 & 17.63 \\
\hline 18 & \pm 0.71 & \pm 0.001 & \pm 0.05 & \pm 4.29 & \pm 39.61 & \pm 15.65 & \pm 1.84 & \pm 15.43 & \pm 15.12 & \pm 1.52 \\
\hline 10 & 18.20 & 4.55 & 0.63 & 24.00 & 456.82 & 173.92 & 14.90 & 140.14 & 114.32 & 17.52 \\
\hline 19 & \pm 0.01 & \pm 0.001 & \pm 0.05 & \pm 3.85 & \pm 38.02 & \pm 21.07 & \pm 2.30 & \pm 14.79 & \pm 17.70 & \pm 1.64 \\
\hline 20 & 18.20 & 4.55 & 0.68 & 26.05 & 495.50 & 185.41 & 15.13 & 151.97 & 118.07 & 18.20 \\
\hline 20 & \pm 0.01 & \pm 0.001 & \pm 0.06 & \pm 3.26 & \pm 46.09 & \pm 23.11 & \pm 2.06 & \pm 16.51 & \pm 12.15 & \pm 0.75 \\
\hline & 18.20 & 4.55 & 0.69 & 24.91 & 490.15 & 198.04 & 14.79 & 149.01 & 117.39 & 17.52 \\
\hline 21 & \pm 0.01 & \pm 0.001 & \pm 0.05 & \pm 3.98 & \pm 40.52 & \pm 15.75 & \pm 2.24 & \pm 8.29 & \pm 18.60 & \pm 1.64 \\
\hline & 18.20 & 4.55 & 0.67 & 25.94 & 486.05 & 189.17 & 14.56 & 149.47 & 121.03 & 17.86 \\
\hline 22 & \pm 0.01 & \pm 0.001 & \pm 0.06 & \pm 3.84 & \pm 50.80 & \pm 24.06 & \pm 1.89 & \pm 11.26 & \pm 12.14 & \pm 1.25 \\
\hline & 18.20 & 4.55 & 0.65 & 24.12 & 464.78 & 184.84 & 14.67 & 152.77 & 117.96 & 17.86 \\
\hline 23 & \pm 0.01 & \pm 0.001 & \pm 0.05 & \pm 2.56 & \pm 38.25 & \pm 17.59 & \pm 1.92 & \pm 12.44 & \pm 9.90 & \pm 1.21 \\
\hline & 18.20 & 4.55 & 0.63 & 22.86 & 455.11 & 175.86 & 13.88 & 149.01 & 115.68 & 17.75 \\
\hline 24 & \pm 0.71 & \pm 0.001 & \pm 0.07 & \pm 1.27 & \pm 55.12 & \pm 24.76 & \pm 1.01 & \pm 9.75 & \pm 8.66 & \pm 1.39 \\
\hline & 18.20 & 4.55 & 0.63 & 23.77 & 449.77 & 178.59 & 14.33 & 149.47 & 113.07 & 17.52 \\
\hline 25 & \pm 0.01 & \pm 0.001 & \pm 0.06 & \pm 4.05 & \pm 56.61 & \pm 21.18 & \pm 1.94 & \pm 17.83 & \pm 14.33 & \pm 2.19 \\
\hline
\end{tabular}

Data of each population are means of 40 adult females.

Populations 1 to 14 from Goiana; populations 15 to 22 from Timbaúba; populations 23 to 30 from Barreiros. 
A. M. JESUS et al.

Table 1. Continuation.

\begin{tabular}{|c|c|c|c|c|c|c|c|c|c|c|}
\hline \multirow[b]{2}{*}{ Population } & \multicolumn{10}{|c|}{ Parameter: mean/ standard deviation } \\
\hline & $\mathrm{SL}(\mu \mathrm{m})$ & $\begin{array}{l}\text { SBD } \\
(\mu \mathrm{m})\end{array}$ & $\begin{array}{c}\mathrm{L} \\
(\mathrm{mm})\end{array}$ & $\mathrm{BD}(\mu \mathrm{m})$ & $\begin{array}{l}\mathrm{AEV} \\
(\mu \mathrm{m})\end{array}$ & $\mathrm{T}(\mu \mathrm{m})$ & $\begin{array}{c}\mathrm{AD} \\
(\mu \mathrm{m})\end{array}$ & $\begin{array}{l}\text { LEE } \\
(\mu \mathrm{m})\end{array}$ & LEIJ & BDS \\
\hline \multirow{2}{*}{26} & 18.09 & 4.55 & 0.65 & 25.14 & 461.48 & 186.10 & 14.45 & 147.88 & 113.75 & 17.63 \\
\hline & \pm 0.01 & \pm 0.001 & \pm 0.05 & \pm 3.41 & \pm 46.02 & \pm 22.40 & \pm 2.27 & \pm 18.08 & \pm 13.97 & \pm 1.83 \\
\hline \multirow{2}{*}{27} & 18.20 & 4.55 & 064 & 25.37 & 459.10 & 182.80 & 14.79 & 149.01 & 113.98 & 17.52 \\
\hline & \pm 0.71 & \pm 0.001 & \pm 0.06 & \pm 4.10 & \pm 33.16 & \pm 28.58 & \pm 2.24 & \pm 11.32 & \pm 8.17 & \pm 1.64 \\
\hline \multirow{2}{*}{28} & 18.20 & 4.55 & 064 & 23.89 & 460.12 & 178.93 & 14.45 & 143.21 & 109.43 & 17.63 \\
\hline & \pm 0.01 & \pm 0.001 & \pm 0.05 & \pm 3.37 & \pm 46.73 & \pm 22.39 & \pm 1.75 & \pm 18.71 & \pm 11.33 & \pm 1.52 \\
\hline \multirow{2}{*}{29} & 18.09 & 4.55 & 0.70 & 25.48 & 501.41 & 198.84 & 14.79 & 157.77 & 122.96 & 18.09 \\
\hline & \pm 0.01 & \pm 0.001 & \pm 0.06 & \pm 4.58 & \pm 52.31 & \pm 23.68 & \pm 2.24 & \pm 18.81 & \pm 14.66 & \pm 1.25 \\
\hline \multirow{2}{*}{30} & 18.20 & 4.55 & 0.63 & 24.23 & 454.09 & 177.68 & 14.79 & 142.64 & 105.67 & 17.97 \\
\hline & \pm 0.71 & \pm 0.001 & \pm 0.05 & \pm 2.98 & \pm 44.73 & \pm 18.43 & \pm 1.99 & \pm 14.51 & \pm 10.06 & \pm 1.00 \\
\hline \multirow[t]{2}{*}{ Population } & \multicolumn{10}{|c|}{ Parameter: mean/ standard deviation } \\
\hline & A & B & $\mathbf{C}$ & $\mathbf{V}$ & BL & CL & & & & \\
\hline \multirow[b]{2}{*}{1} & 23.64 & 4.58 & 3.55 & 71.59 & 71.59 & 11.68 & \multirow{2}{*}{\multicolumn{4}{|c|}{ P. zeae }} \\
\hline & \pm 3.24 & \pm 0.67 & \pm 0.31 & \pm 2.89 & \pm 2.98 & \pm 2.86 & & & & \\
\hline $1 \mathbf{a}$ & 29.60 & 4.35 & 5.25 & 85.81 & 5.10 & 7.05 & \multicolumn{4}{|c|}{ Pratylenchus sp. } \\
\hline & 22.44 & 4.29 & 10.90 & 71.13 & 5.58 & 3.57 & & & & \\
\hline 2 & \pm 3.51 & \pm 0.66 & \pm 1.85 & \pm 4.07 & \pm 1.11 & \pm 0.46 & & & & \\
\hline 3 & 24.39 & 4.50 & 3.55 & 71.77 & 5.75 & 11.65 & & & & \\
\hline $\boldsymbol{J}$ & \pm 2.93 & \pm 0.63 & \pm 0.28 & \pm 4.20 & \pm 0.67 & \pm 1.47 & & & & \\
\hline 4 & 24.90 & 4.61 & 3.55 & 71.78 & 5.87 & 12.42 & & & & \\
\hline 4 & \pm 3.92 & \pm 0.62 & \pm 0.23 & \pm 1.93 & \pm 0.74 & \pm 1.81 & & & & \\
\hline 5 & 25.27 & 4.38 & 3.56 & 71.78 & 5.82 & 12.04 & & & & \\
\hline 5 & \pm 3.43 & \pm 0.63 & \pm 0.29 & \pm 2.50 & \pm 0.96 & \pm 1.78 & & & & \\
\hline & 25.64 & 4.68 & 3.53 & 71.90 & 6.04 & 12.67 & & & & \\
\hline 6 & \pm 3.36 & \pm 0.61 & \pm 0.30 & \pm 3.08 & \pm 0.72 & \pm 1.97 & & & & \\
\hline & 26.08 & 4.34 & 3.56 & 71.68 & 0.86 & 12.13 & & & & \\
\hline 7 & \pm 2.70 & \pm 0.61 & \pm 0.21 & \pm 1.89 & \pm 5.87 & \pm 2.23 & & & & \\
\hline 8 & 25.18 & 4.25 & 3.58 & 71.38 & 5.88 & 12.26 & & & & \\
\hline 8 & \pm 2.49 & \pm 0.47 & \pm 0.25 & \pm 3.39 & $\pm 0,86$ & \pm 1.79 & & & & \\
\hline & 27.11 & 4.27 & 3.59 & 71.99 & 5.77 & 12.59 & & & & \\
\hline 9 & \pm 3.90 & \pm 0.60 & \pm 0.30 & \pm 2.05 & \pm 0.71 & \pm 2.07 & & & & \\
\hline 10 & 27.75 & 4.55 & 3.51 & 73.51 & 6.13 & 13.35 & & & & \\
\hline 10 & $\pm 3,32$ & \pm 0.61 & \pm 0.13 & \pm 0.13 & \pm 0.91 & \pm 1.95 & & & & \\
\hline $10 \mathrm{a}$ & 20.85 & 3.49 & 5.50 & 78.40 & 4.55 & 4.63 & & Pratyle & chus $\mathrm{sp}$ & \\
\hline & \pm 28.33 & \pm 4.46 & \pm 8.67 & \pm 85.33 & \pm 6.40 & \pm 6.83 & & Pratyle & chus sp. & \\
\hline 11 & 25.92 & 4.42 & 3.56 & 71.87 & 5.80 & 12.42 & & & & \\
\hline & \pm 3.23 & \pm 0.49 & \pm 0.21 & \pm 1.64 & \pm 0.49 & \pm 1.80 & & & & \\
\hline 12 & $\begin{array}{c}26.85 \\
\pm 4.44\end{array}$ & $\begin{array}{c}4.29 \\
\pm 0.44\end{array}$ & $\begin{array}{c}12.32 \\
\pm 2.04\end{array}$ & $\begin{array}{c}72.22 \\
\pm 2.05\end{array}$ & $\begin{array}{c}5.73 \\
\pm 0.56\end{array}$ & $\begin{array}{c}3.66 \\
\pm 0.26\end{array}$ & & & & \\
\hline $12 a$ & $\begin{array}{c}20.00 \\
\pm 23.20\end{array}$ & $\begin{array}{c}3.74 \\
\pm 3.79\end{array}$ & $\begin{array}{c}9.00 \\
\pm 10.3 \\
3\end{array}$ & $\begin{array}{c}73.28 \\
\pm 78.40\end{array}$ & $\begin{array}{c}4.62 \\
\pm 4.64\end{array}$ & $\begin{array}{c}3.74 \\
\pm 4.63\end{array}$ & & Pratyle & chus sp. & \\
\hline 13 & 27.72 & 4.50 & 12.85 & 71.58 & 5.97 & 3.53 & & & & \\
\hline 13 & \pm 3.25 & \pm 0.56 & \pm 1.74 & \pm 1.69 & \pm 0.70 & \pm 0.21 & & & & \\
\hline 14 & 26.30 & 4.38 & 13.09 & 72.10 & 5.84 & 3.46 & & & & \\
\hline $14 \mathrm{a}$ & $\begin{array}{c} \pm 5.60 \\
26.60\end{array}$ & $\begin{array}{c} \pm 0.88 \\
3.69\end{array}$ & $\begin{array}{c} \pm 1.86 \\
9.67\end{array}$ & $\begin{array}{l} \pm 2.19 \\
80.45\end{array}$ & $\begin{array}{c} \pm 1.18 \\
5.54\end{array}$ & $\begin{array}{c} \pm 0.54 \\
4.59\end{array}$ & & Pratule & chus sn & \\
\hline & $\begin{array}{l}20.00 \\
27.02\end{array}$ & $\begin{array}{l}5.09 \\
4.59\end{array}$ & $\begin{array}{c}9.0 / \\
12.60\end{array}$ & $\begin{array}{l}80.45 \\
71.72\end{array}$ & $\begin{array}{l}5.54 \\
5.94\end{array}$ & $\begin{array}{l}4.59 \\
3.51\end{array}$ & & Pralye & chus sp. & \\
\hline 15 & $\begin{array}{l}+0.09 \\
\pm 3.09\end{array}$ & \pm 0.51 & \pm 1.70 & \pm 2.51 & \pm 0.66 & \pm 0.23 & & & eae & \\
\hline 16 & 24.64 & 4.55 & 12.65 & 71.41 & 5.86 & 3.51 & & & & \\
\hline 16 & \pm 3.11 & \pm 0.48 & \pm 1.91 & \pm 1.90 & \pm 0.55 & \pm 0.23 & & & & \\
\hline & 27.61 & 4.64 & 14.23 & 70.84 & 5.89 & 3.44 & & & & \\
\hline 17 & \pm 2.98 & \pm 0.48 & \pm 1.88 & \pm 1.84 & \pm 0.71 & \pm 0.20 & & & & \\
\hline 18 & 25.19 & 4.34 & 13.03 & 71.86 & 5.42 & 3.55 & & & & \\
\hline 18 & \pm 3.59 & \pm 0.55 & \pm 1.51 & \pm 1.26 & \pm 0.65 & \pm 0.15 & & & & \\
\hline 19 & 26.76 & 4.54 & 11.93 & 72.46 & 5.62 & 3.65 & & & & \\
\hline 19 & \pm 3.70 & \pm 0.57 & \pm 2.36 & \pm 1.93 & \pm 0.85 & \pm 0.27 & & & & \\
\hline 20 & 26.41 & 4.52 & 12.49 & 72.72 & 5.82 & 3.80 & & & & \\
\hline 20 & \pm 3.22 & \pm 0.45 & \pm 1.98 & \pm 2.40 & \pm 0.51 & \pm 0.32 & & & & \\
\hline & 28.08 & 4.63 & 13.55 & 71.18 & 5.72 & 3.48 & & & & \\
\hline 21 & \pm 3.40 & \pm 0.45 & \pm 1.33 & \pm 1.63 & \pm 0.59 & \pm 0.19 & & & & \\
\hline 22 & 26.22 & 4.50 & 13.11 & 72.57 & 5.58 & 3.59 & & & & \\
\hline & \pm 3.70 & \pm 0.48 & \pm 2.02 & \pm 3.50 & \pm 0.69 & \pm 0.31 & & & & \\
\hline
\end{tabular}

Data of each population are means of 40 adult females.

Populations 1 to 14 from Goiana; populations 15 to 22 from Timbaúba; populations 23 to 30 from Barreiros.

Rev. Caatinga, Mossoró, v. 33, n. 3, p. 599 - 607, jul. - set., 2020 
A. M. JESUS et al.

Table 1. Continuation.

\begin{tabular}{|c|c|c|c|c|c|c|c|}
\hline \multirow{2}{*}{ Population } & \multicolumn{7}{|c|}{ Parameter: mean/ standard deviation } \\
\hline & $\mathbf{A}$ & B & C & $\mathbf{V}$ & BL & $\mathbf{C L}$ & \\
\hline \multirow[b]{2}{*}{23} & 27.10 & 4.27 & 12.75 & 71.57 & 5.53 & 3.52 & \multirow[b]{2}{*}{ P. zeae } \\
\hline & \pm 2.54 & \pm 0.41 & \pm 1.69 & \pm 1.72 & \pm 0.52 & \pm 0.21 & \\
\hline \multirow{2}{*}{24} & 27.69 & 4.25 & 12.68 & 71.97 & 5.47 & 3.63 & \multirow{2}{*}{ P. zeae } \\
\hline & \pm 3.15 & \pm 0.50 & \pm 1.58 & \pm 2.42 & \pm 0.56 & \pm 0.32 & \\
\hline \multirow{2}{*}{25} & 26.83 & 4.24 & 12.60 & 71.57 & 5.61 & 3.52 & \multirow{2}{*}{ P. zeae } \\
\hline & \pm 3.61 & \pm 0.60 & \pm 1.81 & \pm 1.20 & \pm 0.76 & \pm 0.16 & \\
\hline \multirow{2}{*}{26} & 26.05 & 4.42 & 13.16 & 71.27 & 5.76 & 3.50 & \multirow{2}{*}{ P. zeae } \\
\hline & \pm 3.11 & \pm 0.56 & \pm 2.56 & \pm 2.21 & \pm 0.77 & \pm 0.26 & \\
\hline \multirow{2}{*}{27} & 25.71 & 4.32 & 12.51 & 71.66 & 5.66 & 3.56 & \multirow{2}{*}{ P. zeae } \\
\hline & \pm 3.21 & \pm 0.41 & \pm 1.93 & \pm 2.78 & \pm 0.59 & \pm 0.33 & \\
\hline \multirow{2}{*}{28} & 27.12 & 4.54 & 12.50 & 71.98 & 5.90 & 3.60 & \multirow{2}{*}{ P. zeae } \\
\hline & \pm 3.29 & \pm 0.72 & \pm 1.80 & \pm 4.46 & \pm 0.75 & \pm 0.32 & \\
\hline \multirow{2}{*}{29} & 27.94 & 4.49 & 13.61 & 71.56 & 5.76 & 3.54 & \multirow{2}{*}{ P. zeae } \\
\hline & \pm 3.16 & \pm 0.53 & \pm 1.82 & \pm 1.56 & \pm 0.73 & \pm 0.18 & \\
\hline \multirow{2}{*}{30} & 26.31 & 4.46 & 12.14 & 71.86 & 6.01 & 3.56 & \multirow{2}{*}{ P. zeae } \\
\hline & \pm 3.08 & \pm 0.50 & \pm 1.47 & \pm 1.56 & \pm 0.67 & \pm 0.19 & \\
\hline
\end{tabular}

Data of each population are means of 40 adult females.

Populations 1 to 14 from Goiana; populations 15 to 22 from Timbaúba; populations 23 to 30 from Barreiros.

Females showed continuous lip region (Figure 1A), average stylet length from 18.09 to $18.31 \mu \mathrm{m}$, rounded and nonfunctional spermatheca (Figure 2C), and subacute and smooth tail terminus with variations (Figures 2F-L), classifying the subpopulation as P. zeae (OLOWE; CORBETT, 1984; CASTILLO; VOVLAS, 2007). In addition, the average value of $\mathrm{V} \%$ varied from 70 to 72 in this species, indicating an important character for identifying P. zeae. This is a parthenogenetic species (rare males), and V\% value is the lowest among the studied species. Morphometric data related to amphimictic subpopulations (populations 10a, 12a, and 14a) showed a similarity with P. penetrans.

Among the most important morphometric variables for identifying this species is $\mathrm{V} \%$ value with an average of 73 to 80 (Table 1), which are in accordance with previous reports (CASTILLO; VOVLAS, 2007). The variables V\% and stylet length from the first studied population had the highest values found in this study. Morphometric data related to this parthenogenetic subpopulation evidenced that the species is a P. brachyurus since it had a stylet length of $22.75 \mu \mathrm{m}$ and $\mathrm{V} \%$ value of 85.81, as shown in (Table 1).

Morphological analysis evidenced an angular lip region with continuous lip plate, spherical, strong, and well developed stylet basal nodules, nonfunctional spermatheca, and hemispheric and smooth tail terminus, in addition to the absence of males (Figure 5), fitting in the description of $\mathrm{P}$. brachyurus population (CASTILLO; VOVLAS, 2007). The other morphometric variables included in (Table 1) were less important to identify the species when compared to those mentioned.

Some populations of Pratylenchus were atypical in relation to $\mathrm{P}$. zeae; for example, population 1a, which exhibited morphometric characters similar to those of P. brachyurus. Other populations (10a, 12a, and 14a) showed males similar to $P$. penetrans. Although some morphometric characteristics can be modified by biotic and abiotic factors (DOUCET et al., 2001), the presence of other Pratylenchus species is expected, as reported by Bellé et al. (2014) in sugarcane plantations in south Brazil.

The identification of Pratylenchus species is based on morphological and/or morphometric differences of each species. However, their general morphology is similar, making it even more difficult to identify them. This low similarity level is applicable only when populations come from different geographical regions, which suggests that Pratylenchus genome is highly variable, in addition to inter- and intraspecific variability for Pratylenchus species. This problem tends to worsen when a mixed population occurs in the same area. The taxonomy of this genus is often questioned and special attention must be paid in species determination.

Fast recognition and identification are premise and benefit for making effective control plan. Although studies performed for identifying Pratylenchus species must be used in the molecular analysis (YU et al., 2012; MOKRINI et al., 2013; NORONHA et al., 2017), morphological characterization of the root lesion nematode is indispensable and provide base data for nematode identification.

\section{CONCLUSIONS}

Pratylenchus zeae is ordinarily present in the sugarcane crop-growing areas of Goiana, Timbaúba and Barreiros of Pernambuco state, although atypical root lesion nematode species may occur in a lower amount and frequency. Further studies to clarify the identity and distribution of these other species are 
encouraged.

\section{REFERENCES}

BELLÉ, C. et al. Fitonematoides associados à cultura da cana-de-açúcar no Rio Grande do Sul, Brasil. Nematropica, 44: 207-217, 2014.

BELLÉ, C. et al. Reaction of sugarcane genotypes to parasitism of Meloidogyne javanica and Pratylenchus zeae. Revista Caatinga, 30: 530-535, 2017.

BEZOOIJEN, J. V. Methods and techniques for nematology. Wageningen: Wageningen University, 2006. 112 p.

CASTILlO, P.; VOVLAS, N. Pratylenchus (Nematoda: Pratylenchidae): Diagnosis, biology, pathogenicity and management. Leiden: Brill, 2007. $529 \mathrm{p}$.

CHAVES, A. et al. Incidência de Meloidogyne spp. e Pratylenchus sp. em cana-de-açúcar no Estado de Pernambuco, Brasil. Nematologia Brasileira, 33: 278-280, 2009.

DOUCET, M. et al. Temperature induced morphometrical variability in an isolate of Pratylenchus vulnus Allen \& Jensen, 1951 (Nematoda: Tylenchida). Nematology, 3: 1-8, 2001.

GONZAGA, V.; SANTOS, J. M. Estudo comparativo da multiplicação in vitro de seis espécies de Pratylenchus em cilindros de cenoura. Nematologia Brasileira, 34: 226 -230, 2010.

JENKINS, W. R. A rapid centrifugal-flotacion technique for separating nematodes from soil. Plant Disease Reporter, 48: 692, 1964.

MARANHÃO, S. R. V. L. et al. Nematode abundance and diversity in sugarcane fields in Brazil. Tropical Plant Pathology, 43: 485-498, 2018.

MAI, W. F. et al. Plant-parasitic nematodes: a pictorial key to genera. Ithaca: Cornell University Press, 1996. 277 p.

MOKRINI, F. et al. Quantitative detection of the root-lesion nematode Pratylenchus penetrans using qPCR. European Journal of Plant Pathology, 137: 403-413, 2013.

NORONHA, M. A. et al. Meloidogyne and Pratylenchus species in sugarcane fields in the state of Alagoas, Brazil. Ciência Rural, 47: 1-3, 2017.
OLIVEIRA, A. Sugarcane technology and Research. Florida, USA: Intechopen, 2018. 122 p.

OLOWE, T.; CORBETT, D. C. M. Morphology and morphometrics of Pratylenchus brachyurus and $P$. zeae II. Influence of environmental factors. Indian Journal of Nematology, 14: 6-17, 1984.

OVERSTREET, C. et al. Site specific nematode management-development and success in cotton production in the United States. Journal of Nematology, 46: 309-320, 2014.

PORTO, A. C. F. et al. Management of PlantParasitic Nematodes on Sugarcane under Tropical Conditions In: SINGH, P.; TWARI, A. K. (Eds.). Sustainable Sugarcane Production. New Jersey, USA: Apple Academic Press, 2018. 1 ed., cap. 11, p. $1-426$.

RAMOUTHAR, P. V.; BHUIYAN, S. A. Nematode parasite of sugarcane. In: SIKORA et al. (Eds.). Plant parasitic nematodes in subtropical and tropical agriculture. Boston, USA: CABI International, 2018. 3 ed., cap. 18, p. 658-686.

SAS Institute. Certification Prep Guide: Base Programming for $\mathrm{SAS}^{\circledR} 9$, fourth ed. Cary, North Carolina: SAS Institute Inc., 2017. 582 p.

SILVA, L. M. A. et al. Seasonal variation of plantparasitic nematodes and relationship with nutritional and growth properties of sugarcane plantations. Tropical Plant Pathology, 42: 132-136, 2017.

SILVA, M. S. et al. Comportamento de genótipos RB de cana-de-açúcar ao parasitismo dos nematoides das galhas. Revista Brasileira de Ciências Agrarias, 11: 73-79, 2016.

YU, Y. T. et al. A review of root lesion nematode: identification and plant resistance. Advances in Microbiology, 2: 411-416, 2012. 